\title{
POLNOHOSPODÁRSKE NÁRADIE V STREDOVEKU Z POHLADU ČESKEJ A SLOVENSKEJ ARCHEOLÓGIE - VÝVOJOVÉ TENDENCIE A PERSPEKTÍVY ĎALŠIEHO VÝSKUMU
}

\author{
ZUZANA BORZOVÁ
}

\begin{abstract}
Abstrakt: Pestovanie kultúrnych plodin, zmeny v polnohospodárskych systémoch, vývoj polnohospodárskeho náradia, inovácie v chove zvierat - to sú významné činitele, ktoré ovplyvňovali chod stredovekej spoločnosti. Napriek tejto skutočnosti problematika stredovekého polnohospodárstva v minulosti nepatrila k preferovaným témam v československej archeológii. Zámerom príspevku je informovat'o vývoji výskumu stredovekého pol'nohospodárstva so zameraním na polnohospodárske náradie v réžii česko-slovenskej archeológie. Príspevok má ponúknut prierez bádania o danej téme od počiatkov záujmu o stredoveké polnohospodárske náradie až po dnešné prístupy k danej problematike. Ďalšim zámerom tohto príspevku je poukázat’ na celoživotný záujem a doposial' neprekonanú prácu Magdaleny Beranovej v oblasti výskumu stredovekého polnohospodárstva.
\end{abstract}

Kl'účové slová: polnohospodárske náradie - agrárne postupy - metódy výskumu - odborné práce s agrárnou tematikou.

Farming tools in the Middle Ages through the prism of Czech and Slovak archaeology: development trends and perspectives of further research

\begin{abstract}
The cultivation of culture crops, changes in farming systems, the development of farming tools, innovations in the breeding of animals - all these played a crucial part in the run of medieval society. Nonetheless, the issues of medieval farming were not among the priorities of Czechoslovak archaeology in the past. The article seeks to bring information about the development of research into medieval farming, with emphasis on farming tools as addressed by Czechoslovak archaeology. The contribution presents an overview of research into the subject, from the onset of interest in medieval farming tools to the current approaches to it, and points out the lifelong interest and unparalleled work of the researcher Magdalena Beranová in the field of medieval farming.
\end{abstract}

Key words: farming tools - agricultural procedures - research methods - specialist literature on the subject of agriculture.

\section{Úvod}

Pol’nohospodárstvo zohráva dôležitú úlohu pri zabezpečovaní obživy obyvatel'stva, a to nielen v stredoveku. V užšom slova zmysle zahŕňa súbor aktivít, z ktorých dominantné sú predovšetkým obrábanie pôdy, pestovanie pol'nohospodárskych plodín a chov hospodárskych zvierat. Hlavnými produktmi sú potraviny pre obyvatel'stvo, krmoviny pre hospodárske zvieratá, vedlajšími zase suroviny pre d’alšie odvetvia. V širšom ponímaní možno do komplexu danej problematiky zaradit' súbor širšie stavaných otázok a tém, ktoré súvisia s ekonomikou, technikou a remeselnou výrobou, so spracovaním a využitím pol'nohospodárskych produktov, so zásobovaním, ako aj s niektorými faktormi, ktoré determinovali koexistenciu človeka a prírody, resp. úlohu človeka pri formovaní kultúrnej krajiny. Stopy po (niektorých) vyššie zmienených aktivitách a produktoch sa $\mathrm{v}$ archeologickom kontexte prejavujú prostredníctvom mnohých artefaktov, ekofaktov, nálezových situácií a javov. Na ich základe (a na základe ostatných prameňov) vzniká predstava o stredovekom pol'nohospodárstve. Jedným z dôležitých dokladov pol'nohospodárstva v mnohých smeroch je polnohospodárske náradie. O tom, v akom rozsahu a o akých výsledkoch v bádaní o stredovekom pol'nohospodárstve možno hovorit', pojednáva predložený príspevok.

\section{Počiatky záujmu}

Vzhl'adom k predmetnej téme možno záujem o pol’nohospodárske náradie vnímat' už v 18.-19. storočí. V tomto tzv. zberatel'skom období zohrali dôležitú úlohu rôzne regionálne historické 
a archeologické spolky a spoločnosti, ako aj iné učené spoločnosti, ktoré medzi inými svojimi aktivitami mali za ciel' zbierat' a zachraňovat' „starožitnosti“, teda aj pol'nohospodárske náradie. Jednou z nich bola tzv. Vlastenecká hospodářská společnost v Prahe, ktorej sekretár J. Mehler založil zbierku pol’nohospodárskeho náradia. Mehlerova zbierka dokumentuje pretrvávanie regionálnych typov plazových a bezplazových radiel (hákov) vedla záhonového pluhu od stredoveku (Válka 2014, 16). Ďalšou podobnou spoločnost'ou bola tzv. Moravskoslezská společnost pro zvelebeni orby, př́rodovědy a vlastivědy, ktorej sekretárom bol Ch. K. André (Válka 2014, 16).

V prvej polovici 19. storočia vznikali tzv. kabinety na stredných školách, ktoré taktiež zbierali a zhromažd’ovali archeologické nálezy. Tie primárne slúžili ako didaktické pomôcky pri výučbe a praktickej prezentácii „starožitností“ ako dokladov života človeka v minulých dobách. Archeologické nálezy boli taktiež sprístupňované širšej verejnosti vo forme výstav (Polla 1996, 7, 70). Podl'a vzoru školských kabinetov, a možno aj nejaký čas pred ich vznikom, súkromní zberatelia - jednotlivci taktiež zhromažd’ovali archeologické nálezy a zakladali súkromné zbierky. Takto zhromaždené artefakty sa neskôr stali základom zbierkových fondov múzeí. Tie vo väčšom počte vznikajú v strednej Európe v druhej polovici a koncom 19. storočia a disponujú aj nálezmi pol’nohospodárskeho náradia (nielen) zo stredoveku (Müller 1982, 8; Polla 1996, 67 nn.). Do tohto obdobia možno datovat' aj vznik Matice slovenskej (r. 1863) a tzv. Matičného múzea (r. 1865) a jeho prvej expozície v roku 1870 (Polla 1996, 67). V tomto období vzniká aj jedna z najstarších a najväčších zbierok stredovekého pol'nohospodárskeho náradia zo strednej Európy, ktorá je verejnosti sprístupnená v roku 1870 v Mad’arskom národnom múzeu - Historickom múzeu (Müller 1982, 8). Pol’nohospodárske náradie sa však objavuje aj v ostatných (mestských) múzeách, napr. v Tábore, odkial' je známa inventárna kniha Mestského múzea v Tábore pod názvom Bernardova kniha přirůstků I, zriadená v roku 1896 (Krajíc 2003, 132).

V tomto období sa pol’nohospodárske náradie začína objavovat' aj vd’aka prvým (amatérskym) archeologickým výskumom a prieskumom. Prieskumy realizujú už vyššie zmienené školské kabinety, ktorých ciel'om je rozširovat' svoje zbierky (Polla 1996, 7). Z tohto obdobia pochádza aj niekol'ko hromadných nálezov, $\mathrm{v}$ náplni ktorých bolo aj pol'nohospodárske náradie. V roku 1878 T. Lehoczky počas „pokusného výskumu“ objavil depot pol’nohospodárskeho náradia v Zádielskej doline (Bartošková 1986, 60, 61, obr. 19:A). Ďalší hromadný nález bol vyoraný v roku 1885 v obci Ivanovice v okrese Vyškov (Bartošková 1986, 20; Červinka 1928, 171, tab. XIX). Z mladších nálezov treba spomenút' nález radlice $\mathrm{z}$ tvrdze $\mathrm{v}$ Batňoviciach ned’aleko Úpice, publikovanej K. J. Hrašem (1892).

Vd’aka vyššie zmieneným aktivitám sa pol'nohospodárske náradie dostáva aj do odbornej (nielen archeologickej) spisby. V tomto ohl'ade je potrebné sa opät' zmienit' o sekretárovi Vlasteneckej hospodárskej spoločnosti v Prahe, J. Mehlerovi, ktorý publikoval dielo o pol'nohospodárstve: Die Landwirtschaft des Königreichs Böhmen, z ktorého je vzhl'adom k náplni tohto príspevku najdôležitejší prvý zväzok s názvom Erste Sammlung der böhmischen Ackergeräte z roku 1784 (Jirásek 1968; Válka 2014, 15, 16). V roku 1846 vychádza vo Viedni dielo F. Hlubeka: Die Landwirtschaftslehre. V tejto knihe - náuke o pol'nohospodárstve autor uvádza popisy jednotlivých druhov pol'nohospodárskeho náradia, ako aj jeho grafické vyobrazenie. Pol'nohospodárske náradie z viacerých regiónov Slovenska sa počas zberatel'ského obdobia vzhl'adom k vtedajšej politickej situácii ocitá v Prírodovednom múzeu vo Viedni, alebo v Mad’arskom národnom múzeu v Budapešti. Nové prírastky Mad’arského národného múzea sú od roku 1880 pravidelne publikované v časopise Archaeologiai Értesítő formou zoznamu a krátkeho popisu, miestami aj s obrazovou prílohou (napr. Hampel 1880; 1881; 1882 a i.)

V medzivojnovom období vzrastá záujem o archeológiu, archeologické výskumy a nálezy, medzi ktorými sa objavuje aj pol’nohospodárske náradie. Nálezový fond tohto druhu archeologického prameňa predstavujú predovšetkým exempláre z hromadných nálezov, napríklad z roku 1900 zo Smolnice (Bartošková 1986, 53; Beranová 1968, 519, 520); z roku 1901 z Tvarožnej Lhoty (Bartošková 1986, 52, 53; Červinka 1928, 171, obr. 47), z 20. rokov 20. storočia z depotov z Oslavan (Bartošková 1986, 30; Červinka 1928, 171, tab. XX), zo Semic (Bartošková 1986, 50, 
51; Niederle 1921, 53), z 30. rokov 20. storočia napríklad zo Starej Břeclavi (Bartošková 1986, 53), z Letov u Dobřichovic (Bartošková 1986, 23, 24), z Moravského Svätého Jána (Eisner 1941, 153-171), z Gajár - Pustatiny Vrablicovej (Eisner 1939/1946, 103-104), alebo z Radvane nad Dunajom, časti Žitava z roku 1936 (Bartošková 1986, 64) a i. V tomto období sa pol'nohospodárske náradie prvýkrát vyskytuje vo včasnostredovekých hroboch, napríklad na pohrebisku v Devínskej Novej Vsi, skúmanom v 20. až 30. rokoch 20. storočia (Eisner 1952). Pol'nohospodárske náradie je spolu s ostatnými kovovými predmetmi v tejto dobe v odbornej spisbe uvádzané vel'mi skromne, často bez obrazovej prílohy a iba ako zoznam nájdených predmetov, bez typologického triedenia a $\mathrm{s}$ nejednotnou terminológiou. Odlišný prístup k predmetnej problematike predstavujú diela L. Niederleho, ktorý sa v nich zmieňuje aj o pol'nohospodárstve a pol'nohospodárskom náradí (Niederle 1916; 1917; 1934). Najprínosnejším v tomto smere je nepochybne jeho syntetické dielo Život starých Slovanů z roku 1921, v ktorom autor popisuje nielen nástroje, ale aj prácu s nimi a taktiež pol'nohospodárske systémy. Vd’aka znalosti archeologického materiálu, etnografickým paralelám, výborným jazykovedným znalostiam a s využitím historických prameňov vytvára rekonštrukciu včasnostredovekého pol'nohospodárstva (Niederle 1921, 9-167).

V neposlednom rade treba spomenút' aj tzv. Eisnerov katalóg, ktorý obsahuje spracovanie starého „kmetovského fondu“ etnografického oddelenia Slovenského národného múzea. Katalóg, ktorý zahŕňa aj nálezy pol’nohospodárskeho náradia, bol publikovaný pod názvom Sbierka pamiatok pravekých a pamiatok z počiatku doby dejinnej v muzeume v Turčianskom Sv. Martine (Polla 1996).

Pol'nohospodárske náradie a tematika pol'nohospodárstva sú aj v tomto období prezentované širokej verejnosti, a to prostredníctvom viacerých spolkov. Jedným z nich bolo České zemédělské muzeum, ktoré sa po vzniku republiky transformovalo na Československé zemédělské muzeum, ústav pro studium a povzneseni venkova, dnes Národní zemědělské muzeum, v súčasnosti s modernou expozíciou „Zemědělství“, ktorá sa týka aj stredovekého pol'nohospodárstva (https:// www.nzm.cz/akce/zemedelstvi zo dňa 13. 1. 2020). Národní zemědělské muzeum má svoje pobočky s tematicky rôzne ladenými expozíciami, z ktorých treba spomenút' expozíciu mlynárstva v Kačine pri Kutnej Hore či Múzeum vinárstva, záhradníctva a krajiny vo Valticiach (https:// www.nzm.cz/muzeum-vinarstvi-zahradnictvi-a-krajiny-valtice zo dňa 13. 1. 2020). K najväčším stálym expozíciám so zameraním na pol’nohospodárstvo z územia Slovenska patrí Slovenské pol'nohospodárske múzeum v Nitre, založené v roku 1922. Spočiatku sídlilo v Bratislave pod názvom Zemedelské múzeum v Bratislave a pre verejnost' bolo otvorené v roku 1930. V roku 1960 bolo múzeum premiestnené do Nitry a od 1. 1.1978 patrí pod správu štátneho podniku agrokomplex Národné výstavisko. Okrem výstavných priestorov je súčastou múzea aj skanzen, Nitrianska pol’ná železnica a knižnica. Pol'nohospodárske nástroje zo stredoveku sú súčast’ou stálej expozície pod názvom Najstaršie dejiny pol’nohospodárstva, ktorá vznikla v spolupráci s Archeologickým ústavom SAV v Nitre a sprístupnená verejnosti bola v roku 1994 (Gogová 2011, 87).

\section{Stredoveké pol'nohospodárske náradie v československej archeológii}

V povojnovom období sa predmetná téma objavuje len okrajovo (napr. Filip 1949), alebo v súvislosti s rekonštrukciou včasnostredovekého kováčstva, t. j. experimentálnou výrobou železných predmetov (Eisner 1948; Kořan 1946).

Ďalšie dve dekády 20. storočia sú pre výskum pol’nohospodárskeho náradia vel'mi dôležité. V tejto dobe, aj vd’aka väčšiemu množstvu objavených a publikovaných nálezov pol'nohospodárskeho náradia, vzniká niekol'ko významných prác obsahujúcich prvé odborné spracovanie danej témy. Ide predovšetkým o deskripciu, triedenie a typologicko-chronologickú analýzu viacerých druhov predmetných artefaktov a o rekonštrukciu činností vykonávaných pomocou pol’nohospodárskeho náradia. Týka sa to orbového náradia a jeho častí, teda radlíc a čeriesel (Beranová 1958; 1968; Kudláček 1965; Stará 1956; 1958; 1959; Šach 1961; 1962; 1963; 1968 a i.), ako aj žatevného náradia (Beranová 1957; Říhová 1962), rýlov a železných okutí rýlov a lopát 
(Kramařík 1959; 1960; Schmidt 1957), hrablí (Smetánka 1956), zberového náradia (Beranová 1957, 109-111), nožníc (Beranová 1967) a i. V týchto prácach sa prvýkrát objavuje presnejšia definícia jednotlivých druhov pol’nohospodárskeho náradia, ako aj viaceré termíny súvisiace $\mathrm{s}$ danou problematikou, väčšinou prevzaté z etnologickej terminológie. Na takomto podklade vzniká typológia viacerých druhov náradia, ktorá je väčšinou založená na tvarovej diferencii danej funkciou jednotlivých nástrojov. Väčšina vyššie zmienených prác analyzuje pol'nohospodárske náradie hlavne $\mathrm{z}$ obdobia včasného stredoveku s dôrazom na etnické podložie, $\mathrm{s}$ témami ako napríklad žatevné nástroje západných Slovanov, pol'nohospodárske nástroje starých Mad’arov a pod. V odbornej spisbe sa objavujú aj príspevky so snahou o hodnotenie, resp. rekonštrukciu stredovekého pol'nohospodárstva, zatial' vo vel'mi stručnom rozsahu. V týchto prácach sa pol'nohospodárske náradie spomína v súvislosti s pol'nohospodárskymi činnostami. V tomto kontexte sú publikované aj nové nálezy (Beranová 1963; 1966; Habovštiak 1965; Kudrnáč 1960, okrajovo aj Smetánka 1965 a i.). Bibliografická práca k téme pol'nohospodárstva a pol'nohospodárskeho náradia z územia Čiech, Moravy a Slovenska existuje doposial' len jediná, a to od M. Beranovej (1969). Obsahuje súpis archeologických prác (alebo prác, ktoré sa zaoberajú archeologickým materiálom) $\mathrm{k}$ téme pol'nohospodárstva od neolitu po koniec 12. storočia vo svetovej archeologickej spisbe (so zretel'om k strednej Európe) za roky 1945-1965. Samostatnú čast' predstavuje bibliografia pol'nohospodárskeho náradia (Beranová 1969, 171-194).

Štúdie týkajúce sa problematiky zloženia materiálu, spôsobu výroby, miery opotrebenia a stôp po opravách na pol'nohospodárskom náradí vznikajú už v 50. rokoch (Pleiner 1959; Pleiner-Plzák-Quadrat 1956) a s väčšou intenzitou v 60. rokoch minulého storočia, predovšetkým vd’aka výskumu R. Pleinera $(1962 ; 1965 ; 1967)$. Aj otázka experimentu s pol'nohospodárskym náradím začína byt' riešená v tomto období. F. Šach, etnológ a vtedajší riaditel' Zemědělského muzea, vytvoril rozsiahlu zbierku orbového náradia a pomocou rekonštruovaných oradiel uskutočnil experimentálnu orbu (Šach 1961; Vysloužil 2010, 99).

V nasledujúcich dekádach 20. storočia sa výskumu stredovekého pol'nohospodárskeho náradia venovala predovšetkým M. Beranová. V 70. rokoch upravila typológiu stredovekých kôs (Beranová 1971), venovala sa otázkam nástrojov využívaných v ovocinárstve a vinohradníctve (Beranová 1972) či problematike konského záprahu (Beranová 1970). V roku 1973 popísala nástroj na rezanie krmiva pre zvieratá (Beranová 1973) a v tej istej dekáde vydala aj svoje súhrnné dielo o pol'nohospodárskej výrobe v 11. až 14. storočí (Beranová 1975). Predmetná monografia ponúka exkurz do problematiky pol'nohospodárskej produkcie na pozadí jednotlivých pracovných úkonov v pol'nohospodárstve, od prípravy pôdy a spracovania rastlinných produktov cez záhradkárstvo a ovocinárstvo až po vinohradníctvo. Venuje sa aj problematike živočíšnej výroby od priamych až po nepriame doklady tohto odvetvia pol'nohospodárstva. Rekonštrukciu jednotlivých činností modeluje predovšetkým na základe analýzy archeologického materiálu s využitím dostupných archeobotanických a archeozoologických analýz, etnografických, ojedinele aj ikonografických a písomných prameňov. Napriek tomu, že názov knihy sa vzt’ahuje k vrcholnému stredoveku, autorka pri jednotlivých úkonoch s pol'nohospodárskym náradím spomína aj staršie, predovšetkým včasnostredoveké náradie a jeho jednotlivé druhy, resp. typy.

F. Šach sa nad’alej venuje problematike orbového náradia (nielen) z obdobia stredoveku z pohl'adu etnografie, ikonografie a písomných prameňov (Šach 1977; 1977a).

V 70. rokoch 20. storočia boli publikované d’alšie príspevky k typológii, druhovej škále alebo funkcii pol’nohospodárskeho náradia. K problematike vinohradníctva, resp. vinohradníckych nožov, sa vyjadril V. Frolec (1972), ako aj J. Vignatiová (1973). Problematike tzv. ohreblovitých nástrojov sa venoval J. Kaván (1970). Orbové náradie v súvislosti s nálezom radlice a otky zhodnotila H. Sedláčková (1977) a nálezy včasnonovovekých exemplárov náradia klasifikovali M. Beranová a V. Huml (1970). K nepriamym dokladom práce s radlom patria stopy po orbe, identifikované počas archeologického výskumu (Hrdlička 1972).

V tomto období sú skúmané viaceré včasnostredoveké aglomerácie, z ktorých pochádza väčšia kolekcia pol’nohospodárskeho náradia, napríklad Břeclav-Pohansko (Dostál 1975; 
Kalousek et al. 1977-1978) alebo Pobedim (Bialeková 1979). Takisto aj výskum stredovekých dedín prináša nové nálezy agrárnych nástrojov, napríklad zo stredovekých dedín Konůvky (Šaurová 1973), Pfaffenschlag (Nekuda 1975) a iných (napr. Habovštiak 1971). Tie sú vyhodnocované v rôznej informačnej či grafickej kvalite. Stručného zhrnutia danej témy sme sa v odbornej spisbe 70. rokov minulého storočia dočkali hned' niekol'kokrát, avšak bez výrazného zistenia alebo noviniek (napr. Dostál 1976; Habovštiak 1971; 1977 a i.). Za novú tému v našom prostredí možno pokladat' problematiku pol'nohospodárskeho náradia $\mathrm{v}$ hroboch $\mathrm{z}$ obdobia avarského kaganátu (Kraskovská 1970).

Začiatkom novej dekády vzniká publikácia M. Beranovej (1980) s témou včasnostredovekého pol’nohospodárstva. Kniha je členená do viacerých tematických okruhov týkajúcich sa pol’nohospodárstva na etnickom podklade: predslovanské pol'nohospodárstvo, pol'nohospodárstvo najstarších Slovanov, pol'nohospodárstvo Slovanov na území ČSSR (6.-10. storočie) a pol’nohospodárska produkcia na ostatnom slovanskom území. Podobná schéma ako v monografii z roku 1975 vedie od typologicko-chronologickej analýzy kovových (sú)častí náradia cez rekonštrukciu náradia až po rekonštrukciu jednotlivých pracovných úkonov v pol’nohospodárstve, predovšetkým vo včasnom stredoveku na území ČSSR (Beranová 1980, 167-260). Podobne ako predchádzajúca monografia M. Beranovej, aj táto publikácia nebola desiatky rokov v českej a slovenskej archeologickej spisbe prekonaná a vo všeobecnosti sú autorkine závery a typologické triedenie pol'nohospodárskeho náradia (okrem menších úprav) v archeologických kruhoch podnes uznávané. Zmienená autorka v tom istom roku ešte vydáva príspevok o spôsobe chovu dobytka vo včasnom stredoveku (Beranová 1980a) a o šest' rokov neskôr zhŕňa svoje nové poznatky o funkcii niektorých nástrojov, overené experimentom (Beranová 1986).

Ďalšou prácou týkajúcou sa aj pol’nohospodárskeho náradia, avšak z iného pohl’adu, je monografia A. Bartoškovej o hromadných nálezoch z územia Československa z obdobia včasného stredoveku (Bartošková 1986). Na rozdiel od predchádzajúcich prác o pol’nohospodárskom náradí, v tejto monografii možno nájst' aj katalógovú čast' so stručným popisom každého exemplára, ako aj obrazovú prílohu v podobe tabuliek s jednoduchou kresbou popisovaného predmetu. Práce v podobnej kvalite grafickej stránky a popisných častí sa v tejto dobe objavujú len ojedinele. Jednou z mála takýchto prác je napríklad vyhodnotenie nálezu depotu z Čeboviec (Točík 1983).

$\mathrm{K}$ téme pol'nohospodárskeho náradia možno zaradit' aj príspevok M. Slivku, v ktorom autor popisuje pol'nohospodárske náradie vrcholného a neskorého stredoveku na podklade nálezov týchto artefaktov z oblasti východného Slovenska. Autor sa zaoberá predovšetkým funkciou (nie typológiou) jednotlivých druhov náradia, kde okrem archeologických nálezov vychádza predovšetkým z ikonografických prameňov. Venuje sa aj problematike možnej špecializovanej výroby pol’nohospodárskeho náradia (Slivka 1981). V d’alšom zhrňujúcom príspevku sa v skratke dozvedáme o nových nálezoch pol’nohospodárskeho náradia zo stredovekých dedín z územia dnešného Slovenska (Čaplovič et al. 1985, 17 nn.). K materiálnej kultúre stredovekej dediny, $\mathrm{k}$ triedeniu a terminológii pol'nohospodárskeho náradia sa viažu aj d’alšie príspevky z tejto dekády (napr. Belcredi 1983; 1988; 1989; Krajíc 1984 a i.). Výsledky archeologického výskumu českej stredovekej dediny za roky 1971 až 1981, vrátane pol’nohospodárskej činnosti, zhodnotili J. Klápště a Z. Smetánka (1982).

Z pohl'adu témy predloženého príspevku mi nedá nespomenút' ešte dve práce z 80 . rokov, ktoré sú však mimo československú obec, no napriek tomu obsahujú informácie o pol’nohospodárskom náradí z územia vtedajšieho Československa. Jednou z nich je dielo J. Henninga: Südosteuropa zwischen Antike und Mittelalter. Schriften zur Ur- und Frühgeschichte 42 (Berlin 1987). Predmetná monografia predstavuje podrobné spracovanie pol’nohospodárskeho náradia z oblasti strednej a juhovýchodnej Európy z obdobia od 1. po 10. storočie. Okrem typologicko-chronologickej analýzy a vyhodnotenia zahŕňa aj detailnú katalógovú čast', obsahujúcu 619 zápisov, t. j. lokalít s výskytom rôznych druhov náradia, ktoré sú presne špecifikované v d’alšom riadku zápisu aj s príslušnou literatúrou. Ďalším dielom je dvojzväzková práca R. Müllera: A mezögazdasági vaseszközök fejlödése Magyarországon a késővaskortól a törökkor végéig. 
Zalai gyüjtemény 19 (Zalaegerszeg 1982). Z hl'adiska výskumu pol’nohospodárskeho náradia ide o doposial' v mnohých smeroch neprekonané dielo. Skladá sa z textovej a katalógovej časti, ktorá obsahuje 2037 exemplárov pol'nohospodárskeho náradia od doby laténskej po neskorý stredovek, resp. novovek z územia dnešného Mad’arska, Rakúska, Slovenska, Rumunska a bývalej Juhoslávie, pričom nálezy mimo územia Mad’arska majú za úlohu objasnit' otázky funkcie, pôvodu alebo datovania konkrétneho druhu náradia. Materiál, ktorý je obsahom tejto práce, pochádza z publikovanej archeologickej spisby, ako aj z muzeálneho nepublikovaného fondu z väčšiny mad’arských múzeí (Müller 1982). Textová čast' sa skladá z typologicko-chronologickej analýzy pol’nohospodárskeho náradia a jeho následného vyhodnotenia vo forme vývoja agrotechniky od doby laténskej po koniec stredoveku. Pre výskum tohto druhu prameňa podáva predmetná monografia ako prvá práca tohto druhu okrem precízne vypracovaného katalógu (s popisom nálezových okolností, príslušnou literatúrou, metrickými údajmi a kresbovým vyobrazením každého predmetu) aj presný popis jednotlivých častí konkrétnych pol'nohospodárskych nástrojov a definuje typologicko-chronologický vývoj jednotlivých druhov nástrojov (napr. Müller 1982, 443, obr. 8). V českej ani slovenskej archeologickej spisbe nepoznám obdobnú prácu.

\section{Česká a slovenská archeológia a problematika stredovekého pol’nohospodárskeho náradia}

V 90. rokoch 20. storočia sa pol’nohospodárske náradie objavuje často v súvislosti s metalografickou analýzou kovových nástrojov, predovšetkým kosákov (napr. Longauerová-Kocich 1993; Longauerová-Kocich-Longauer 1995). Stručne sa o náradí zmieňujú autori v súvislosti s výskumom včasnostredovekých sídliskových aglomerácií, sídlami šlachty alebo s výskumom stredovekých dedín (napr. Měchurová 1997). K danej téme sa opät' vracia aj M. Beranová, predovšetkým v súvislosti so zberovým náradím (Beranová 1990; 1991; 1995). Pre širšiu odbornú aj laickú verejnost' je určená monografia Z. Smetánku (1992) o každodennom živote stredovekého rol'níka Ostoja.

Nárast záujmu o tematiku pol’nohospodárstva, pol’nohospodárskeho náradia, spracovania a d'alšej úpravy pol'nohospodárskych produktov možno badat' v českej a slovenskej archeologickej spisbe v prvej dekáde 21. storočia. V tejto dobe L. Poláček (2003) publikuje výsledky výskumu pol’nohospodárskeho náradia z Mikulčíc. Ide o komplexné spracovanie nástrojov, ktoré boli vo včasnom stredoveku používané k rôznym pracovným úkonom v rámci pol’nohospodárstva. Príspevok obsahuje okrem typologicko-chronologickej a priestorovej analýzy aj kvalitne vypracovanú (slovnú aj grafickú) katalógovú čast'. Takýto prístup pri spracovaní pol’nohospodárskeho náradia v odbornej spisbe dovtedy absentoval, čo je zrejmé z predchádzajúcich riadkov predloženého príspevku. V tom istom roku vychádza d’alšia dôležitá práca $\mathrm{k}$ danej téme. Ide o spracovanie pol’nohospodárskeho náradia z poddanského mesta Sezimovo Ústí (Krajíc 2003). Autor poníma túto problematiku vel’mi komplexne: od dejín bádania cez nálezové okolnosti, vlastnú typológiu až po detailne spracovanú katalógovú čast'. Vd’aka analýze nálezových okolností prichádza R. Krajíc k dôležitým záverom o funkcii niektorých druhov pol'nohospodárskeho náradia aj mimo pol’nohospodárstva. Práca predstavuje vel'mi dôležitý zdroj informácií k problematike pol’nohospodárskeho náradia z 13.-15. storočia $\mathrm{v}$ stredoeurópskom priestore.

Okrem vyššie zmienených prác sa v odbornej spisbe objavuje spracovanie či zmienka o pol'nohospodárskom náradí aj z iných lokalít, avšak už nie v takej kvalite alebo rozsahu ako vo vyššie zmienených príspevkoch. Zo včasnostredovekých aglomerácií sa treba zmienit' o hradisku Bojná I Valy, kde bolo nájdených niekol'ko depotov obsahujúcich aj pol’nohospodárske náradie (Turčan 2006). L. Belcredi (2006) sa zmieňuje o náradí zo stredovekej dediny Bystř̌ec. Pol’nohospodárske náradie zo stredovekých usadlostí stručne spomína R. Nekuda (2002) v súvislosti s jednotlivými pracovnými činnost’ami od orby až po chov dobytka.

V tomto období vychádza aj viacero príspevkov analyzujúcich jeden druh náradia a prácu s týmto náradím. D. Bialeková (2001) vo svojom príspevku analyzuje jeden druh nástroja - česák l'anu z hradiska v Pobedime. O spôsoboch obrábania pôdy sa zmieňuje predovšetkým M. Beranová (2006) a z iného pohl'adu aj P. Vysloužil (2010). Ručným obrábaním pôdy, predovšetkým rýlom, 
ale aj problematikou typológie, spôsobu výroby a foriem použitia rýla sa v tejto dobe zaoberali hlavne J. Musil (2004; 2004a; 2008), ako aj autorka tohto príspevku (Borzová 2010). V odbornej spisbe sa často rieši otázka žatevného a ostatného zberového náradia (napr. Beranová 2000; 2005; Borzová 2009; Michálek-Lutovský 2000). V súvislosti s kosákmi sa v odbornej literatúre objavujú aj práce pojednávajúce o metalografickej analýze tohto druhu pol’nohospodárskeho náradia (napr. Klíma-Ptáček 2006; Klíma-Ptáček-Stránský 2008; Petrík-Mihok 2004). Kosáky, ako aj iné druhy náradia a ich funkcia $\mathrm{v}$ hroboch, sú v odbornej spisbe tiež často sa vyskytujúcou témou (Borzová 2006; Hanuliak 2004; 2004a; Reichenbach 2004).

Ďalšiu skupinu príspevkov predstavujú práce, v ktorých sa autori pokúsili o komparáciu archeologického a etnografického materiálu. Jednou z nich je príspevok Z. Měchurovej (2008) o náradí používanom pri práci na poli v stredoveku a v novoveku. Ďalšie práce prinášajú nové poznatky o súčasnom používaní náradia a techník, ktoré sú známe už zo starších historických období (napr. Borzová-Pažinová 2010; Dreslerová-Venclová 2007).

Z prvej dekády 21. storočia pochádzajú aj príspevky o pol’nohospodárskom náradí, ktoré majú súhrnný charakter. Najkomplexnejším v tomto smere je dielo od autorov M. Beranovej a A. Kubačáka (2010), ktoré poskytuje sumárne poznatky o vývoji českého pol'nohospodárstva od neolitu po rok 1989 z pohl'adu archeologičky a historika. Napriek tomu, že je podl'a vydavatel'stva určené predovšetkým poslucháčom odborných pol’nohospodárskych škôl, považujem ho, tak isto ako aj d’alšie diela M. Beranovej k danej téme z tejto dekády (Beranová 2000; Beranová-Lutovský 2009), za skvelú príručku aj pre poslucháčov archeológie či histórie. Ďalšou pomôckou pre študentov rôznych odvetví pol'nohospodárstva, avšak už menej pre archeológov, sú skriptá kolektívu autorov zo Slovenskej pol'nohospodárskej univerzity v Nitre (Demo et al. 2001).

V súvislosti s danou témou je dôležité upozornit' aj na študentské práce, ktoré sa priamo týkajú témy pol’nohospodárstva a pol'nohospodárskeho náradia. Ide o diplomové (Hlavatá 2008; Vedralová 2009; Vysloužil 2010), ako aj dizertačné práce (Borzová 2005; Klír 2008) z rôznych katedier archeológie z územia Českej republiky a Slovenskej republiky.

Tento trend pokračuje aj v druhej dekáde 21. storočia, kedy problematika pol'nohospodárstva a pol'nohospodárskeho náradia zostáva nad’alej populárna. Dôkazom sú témy bakalárskych prác (napr. Benčič 2012; Hylmanová 2012), ako aj diplomových prác (napr. Hylmanová 2016; Kaličiaková 2013; Valašeková 2014).

V odbornej literatúre sa problematika pol'nohospodárskeho náradia objavuje čoraz častejšie nielen ako zoznam nálezov, ale aj vo forme katalógu so slovným popisom a s metrickými údajmi, ako aj s kvalitnou obrazovou prílohou. Ide predovšetkým o predmety pochádzajúce zo včasnostredovekých hromadných nálezov, napríklad z Bojnej, Divinky, Vel'kého Klíža, Vrbového, Zemianskeho Podhradia (Turčan 2012), z Bratislavy (Kováč 2013) či z Vysokého pole (Geisler-Kohoutek 2014). Podobne sú publikované práce s témou jedného druhu náradia, obsahujúce okrem analytickej časti aj podrobný katalóg nálezov (napr. Borzová 2015; Valašeková 2015). Ten sa už štandardne vyskytuje aj v inak koncipovaných prácach na danú tému (napr. Slaná 2017).

Iného charakteru je zborník príspevkov k téme včasnostredovekého pol'nohospodárstva (Borzová et al. 2015). Publikácia ponúka pohl’ad na danú problematiku nielen z pera archeológov (Borzová 2015; Valašeková 2015), ale aj archeobotaničky (Hlavatá 2015), antropológov (BeňušMasnicová 2015) a historičky (Benková 2015).

V tejto dekáde vzniká súborná práca o pol'nohospodárskom náradí zo včasného stredoveku na Slovensku (Borzová 2016). V zmienenej monografii vidiet' pokus o zjednotenie terminológie (druhovej, typovej, ako aj terminológie jednotlivých častí náradia). Monografia okrem toho obsahuje podrobnú typologicko-chronologickú analýzu a vyhodnotenie jednotlivých druhov pol'nohospodárskeho náradia zo včasného stredoveku väčšinou na základe publikovaných materiálov z územia Slovenska, ako aj rekonštrukciu jednotlivých činností vykonávaných s týmto náradím. Záver práce sa týka aj otázok vlastníctva a druhotnej funkcie náradia, o čom sa ešte zmienim nižšie. Monografia neobsahuje katalógovú čast'. Tá je súčastou dizertačnej práce autorky tohto príspevku (Borzová 2005), ktorá doposial' nebola publikovaná. 
Z pera P. Dreslera a V. Berana (2019) pochádza príspevok o pol’nohospodárskom náradí z Břeclavi-Pohanska. Zmienení autori využívajú okrem klasických archeologických analýz aj metalografické analýzy. Zistené výsledky vedú k zaujímavým hypotézam o hospodárskom fungovaní a technologickej úrovni včasnostredovekej aglomerácie, a tým poukazujú aj na nevyhnutnost' výskumu pol’nohospodárskeho náradia a jeho dôležitého postavenia $\mathrm{v}$ ekonomickom systéme vtedajšej spoločnosti. Metodicky podobne je riešená problematika pol'nohospodárskeho náradia z hradiska Bojná - Valy, kde bolo doposial' nájdených 243 kusov predmetných artefaktov. Typologicko-chronologická analýza, priestorová analýza a výskum miery opotrebenia a stôp po opravách pol’nohospodárskeho náradia vedú k novým zisteniam a zároveň nastol'ujú nové otázky týkajúce sa hospodárskeho fungovania predmetného hradiska (Borzová-Pieta-Jakubčinová $\mathrm{v}$ tlači).

Svoj výpočet najzaujímavejších príspevkov $\mathrm{k}$ danej problematike by som zakončila prácou pre širšiu verejnost' od Z. Měchurovej (2016), v ktorej pol'nohospodárske náradie nadobúda iný rozmer, než na aký sme boli zvyknutí. Náradie je tu prezentované ako priestor pre výzdobný prvok. Význam značiek, ako aj výzdobných motívov zostáva podnes nedoriešenou problematikou.

V súvislosti s prezentáciou pol’nohospodárskeho náradia pre verejnost', okrem už spomínaných múzejných inštitúcií, sa treba zmienit' aj o ostatných inštitúciách. Ide predovšetkým o regionálne múzeá, skanzeny, archeoskanzeny v Českej aj Slovenskej republike, ako aj o niektoré múzeá mimo sledovaného priestoru - predovšetkým Prírodovedné múzeum vo Viedni, Mad’arské národné múzeum v Budapešti a Zakarpatské vlastivedné múzeum v Užhorode. Cenné informácie o pol'nohospodárstve Karpatskej kotliny od neolitu po rok 1945 možno nájst' napríklad aj v Mad’arskom pol'nohospodárskom múzeu, ktoré obsahuje aj archív historických pracovných nástrojov (aj z územia dnešného Slovenska).

\section{Východiská a perspektívy}

Napriek tomu, že výpočet odbornej spisby $\mathrm{k}$ danej téme je $\mathrm{v}$ celku obsiahly, problematika a výskum pol'nohospodárskeho náradia má doposial' svoje medzery, ktoré by mohli byt' vyplnené vd’aka d’alšiemu výskumu v danej oblasti.

V prvom rade ide o nejednotnú terminológiu. S tým sa stretávame už pri primárnej definícii, čiže vymedzení pojmu pol'nohospodárskeho náradia, ktoré je označované aj ako pol’nohospodárske nástroje, predmety z pol'nohospodárstva a i. Takisto vel'mi často v odbornej spisbe absentuje definícia obsahu a druhovej škály pol'nohospodárskeho náradia. Najčastejšie (ak vôbec) je pol’nohospodárske náradie definované ako súbor predmetov, ktorý súvisí s pol’nohospodárskou prvovýrobou (t. j. úpravou pôdy a orbou, vláčením, zberom plodín a chovom dobytka), niekedy sú k tejto skupine pridané aj nástroje, ktoré súvisia so skladovaním a d’alším spracovaním pol'nohospodárskych produktov (napr. česáky l’anu, žarnovy atd'.). Do skupiny pol'nohospodárskeho náradia, resp. do skupiny predmetov, ktoré súvisia s pol'nohospodárskou produkciou, sa radia aj viacúčelové predmety, ktoré boli súčastou vybavenia stredovekej domácnosti (motyka, sekera, nožnice a i.). Kategorizácia týchto predmetov je podmienená ich funkciou v určitom čase a priestore, preto je dôležité pristupovat' $\mathrm{k}$ definovaniu týchto pojmov pri riešení danej problematiky zodpovedne a individuálne, čo častokrát v odbornej spisbe absentuje.

S nejednotnou terminológiou sa stretávame aj pri pomenovaní konkrétneho druhu náradia, predovšetkým pri kosáku/srpe, radlici/lemeši, čeriesle/krájadle/krojidle, motykovom nástroji, otke, a i. Niektoré z nich majú v názve obsiahnuté tvarové znaky, pri ostatných je z názvu/pomenovania zrejmá funkcia daného predmetu ( $\mathrm{k}$ téme napr. Borzová 2016).

Za nedostatok v otázkach výskumu pol’nohospodárskeho náradia možno pokladat' vel'mi častú absenciu detailného popisu náradia a schematického zobrazenia jednotlivých častí, ako aj metrických údajov. Tieto informácie sa v odbornej spisbe objavujú v plne využitel’nej podobe žial' len výnimočne (napr. Borzová 2016; Krajíc 2003), čo st’ažuje prácu s témou. Na tento problém už v minulosti upozornil R. Müller. Podl'a neho by detailný opis železných predmetov 
a ich nálezových okolností mohol viest' $\mathrm{k}$ lepšej analýze a aj k spresneniu datovania sledovaných predmetov (Müller 1982, 558, pozn. 46). S autorom možno len súhlasit'. V otázkach datovania pol'nohospodárskeho náradia častokrát vychádzame z nejasných nálezových okolností, resp. z neúplného archeologického kontextu. Detailný a kvalitný popis nálezových okolností s prislúchajúcou obrazovou prílohou by $\mathrm{v}$ mnohých prípadoch mohol ul'ahčit' nielen datovanie pol’nohospodárskeho náradia, ale aj interpretáciu funkcie, ako aj spôsobu používania, rekonštrukciu celkového vzhl'adu daného predmetu, alebo identifikáciu spôsobu uloženia a zaobchádzania s predmetným pol’nohospodárskym náradím.

Ďalšou z nedoriešených kl’účových tém je typológia pol'nohospodárskeho náradia. Doterajšie typológie analyzovaných predmetov sú založené skôr na tvarovej rozdielnosti, ktorá je často jediným kritériom typologického triedenia. Tak je to napríklad v prípade krátkych kôs, ktoré delíme na typy so zakrivenou a rovnou čepelou (Beranová 1957, 109-111; 2005 a i.; Steensberg 1943, 178-180). Na základe analýzy včasnostredovekých krátkych kôs z územia dnešného Slovenska možno konštatovat', že okrem tvaru čepele sa krátke kosy oboch typov od seba nijako neodlišujú (Borzová 2016, 82). Navyše, na základe novších výsledkov výskumu je zrejmé, že niektoré nástroje rovnakého alebo podobného tvaru majú rozdielnu štruktúru materiálu, čo ich predurčuje k rozdielnej funkcii (Borzová 2015). Preto je dôležité klást' dôraz na funkčné triedenie, resp. zohl'adnit' ho pri definovaní jednotlivých typov pol'nohospodárskeho náradia.

Zabudnút' by sme nemali ani na otázky využitia pol'nohospodárskeho náradia mimo agrárnych aktivít v období stredoveku, predovšetkým v súvislosti s ich výskytom na stredovekých hradoch (napr. Vích 2010).

Rekonštrukcia celkového vzhl’adu pol'nohospodárskeho náradia je d’alšou z tém, ktoré si zaslúžia väčšiu pozornost'. V archeologickom materiáli nachádzame väčšinou len železné (sú)časti náradia. Ostatné, t. j. organické časti týchto artefaktov možno rekonštruovat’ na základe rôznych iných prameňov. Napriek tomu v niektorých prípadoch nie je možné identifikovat' ich celkový tvar. Preto sa stáva, že celkový tvar náradia, ako aj jeho funkcia sú odvodené od jeho železnej časti, čo prináša skresl'ujúce výsledky. Príkladom je motykové náradie, ktorého drevená násada, resp. jej rôzne tvary, ho predurčujú pre použitie na rôzne účely (Borzová 2015; 2016, 46, obr. 41).

V českej a slovenskej, resp. československej odbornej spisbe sa v minulom storočí objavovalo pol'nohospodárske náradie väčšinou v súvislosti $\mathrm{s}$ výskumom a vyhodnotením výsledkov výskumu určitej lokality, s výskumom hromadných nálezov, alebo ako klúčová téma týkajúca sa pol'nohospodárstva. Žial', vo vyššie vymenovaných skupinách príspevkov nachádzame len ojedinele vhodne vypracovaný katalóg nálezov (napr. Bartošková 1986), ktorý by poslúžil d’alšej analýze pol'nohospodárskych nástrojov. K zmene dochádza až začiatkom nového tisícročia, kedy sa súčastou odborných príspevkov stávajú aj obsiahlejšie katalógy, detailnejšia obrazová príloha a kvalitne vypracovaná textová dokumentácia každého náradia (napr. Borzová 2015; Dresler-Beran 2019; Geisler-Kohoutek 2014; Poláček 2003; Turčan 2012), aj ked's rôznou kvalitou a s rôznym množstvom informácií.

Ako d’alší ciel' v nasledujúcom bádaní o danej téme by sme mohli vytýčit' doposial' chýbajúce komplexné spracovanie pol’nohospodárskeho náradia zo skúmaného územia podla vzoru vyššie zmienených prác J. Henninga (1987) a predovšetkým R. Müllera (1982). Teda dielo, ktoré by v súvislosti s výskumom stredovekého pol’nohospodárskeho náradia obsahovalo archeologické, metalografické a trasologické analýzy, vyhodnotenie výsledkov, ako aj komentovaný katalóg s kvalitnou obrazovou prílohou všetkých dostupných pol’nohospodárskych nástrojov z územia Českej republiky a Slovenskej republiky. V tejto súvislosti by bolo zaujímavé (a žiadúce) spracovat' archeologický materiál z celého stredoveku. Analýza a porovnanie výsledkov výskumu pol’nohospodárskeho náradia zo včasného stredoveku na jednej strane a z vrcholného a neskorého stredoveku, prípadne včasného novoveku na druhej strane by mohli priniest' zaujímavé výsledky v otázkach pol'nohospodárskej produkcie a zmien v pol'nohospodárstve, ako aj nové postrehy na poli metód výskumu pol'nohospodárskeho náradia. 
Na škodu veci je aj fakt, že doposial' nebola publikovaná práca, ktorá by sa zaoberala zhodnotením doterajšieho výskumu na danú tému, ak neberieme do úvahy stat' v príspevku J. Klápštěho a Z. Smetánku (1982), alebo kapitolu o histórii bádania k téme od R. Krajíca (2003, 130-131). Téma nie je populárna ani za hranicami sledovaného priestoru. Napríklad v Mad’arsku sa okrem R. Müllera (1982) o metódach výskumu pol’nohospodárstva zmienil iba M. Belényesy v roku 1957.

Vyššie stanovenému ciel'u celkového spracovania danej témy predchádza spracovanie a publikovanie nálezového fondu pol’nohospodárskeho náradia z klúčových včasnostredovekých sídliskových aglomerácií, stredovekých dedín, mestských aglomerácií, sídiel šlachty či hradov. Príkladom je hradisko Pobedim a jeho zázemie, kde bola nájdená väčšia kolekcia pol’nohospodárskeho náradia $\mathrm{v}$ rôznom nálezovom kontexte. Lokalita bola skúmaná v druhej polovici minulého storočia, pričom boli publikované len čiastkové výsledky (Bialeková 1979; 2001; Vendtová 1964; 1969). Spracovanie tohto súboru by nepochybne obohatilo nálezový fond pol'nohospodárskeho náradia, jeho druhovú škálu a v neposlednom rade by mohlo napomôct' riešeniu problematiky hospodárskeho fungovania a technologickej úrovne včasnostredovekej aglomerácie, ako aj vztahov medzi centrom a osadami v jeho blízkosti (k téme Dresler 2016).

Ako vyplýva $z$ viacerých vyššie zmienených téz, pri výskume pol’nohospodárskeho náradia je nevyhnutná interdisciplinárna spolupráca, resp. zohl'adnenie výsledkov výskumu iných vedných disciplín či aplikácia rôznych nearcheologických analýz. V tomto smere má výskum pol'nohospodárskeho náradia, ako aj celkovo pol'nohospodárstva, značné medzery, ktoré by bolo vhodné novým výskumom postupne vypĺn̆at'.

V neposlednom rade chcem ešte upozornit' na zabudnuté témy týkajúce sa danej problematiky. Ide o tematiku, ktorá súvisí s iným pohl’adom na predmety, ktoré určitým spôsobom poukazujú nielen na prácu, ale aj na iné sféry života, na zmýšlanie, zvyky a duchovný svet stredovekého rol'níka. Odpovede by sme mali hladat' v tézach týkajúcich sa starostlivosti o pol'nohospodárske náradie, estetickej stránky, reálnej hodnoty a duchovného významu týchto predmetov.

Práca vznikla v rámci projektu 2/0037/17 agentúry VEGA „Úloha materiálnej kultúry pri formovaní ekonomických, sociálnych a interetnických väzieb v stredovekých komunitách“.

\section{Literatúra}

BARTOŠKOVÁ, A., 1986: Slovanské depoty železných předmětů v Československu. Praha 1986.

BELCREDI, L., 1983: Zemědělské a řemeslnické nástroje na zaniklých stredověkých osadách - Landwirtschaftliches und handwerkliches Gerät aus Ortswüstungen, AH 8, 411-422.

- 1988: Užití kovu ve středověké osadě. Výsledky dosavadního archeologického výzkumu zaniklé středověké osady Bystřec - Die Verwendung von Metall in mittelalterlichen Siedlungen: Ergebnisse der bisherigen Untersuchungen in der MOW Bystřec, AH 13, 459-485.

- 1989: Terminologie, tř́idění a kód středověkých kovových předmětů - Terminologie, Klassifizierung und Kode mittelalterlicher metallischer Gegenstände, AH 14, 437-472.

- 2006: Bystř̌ec. O založení, životě a zániku středověké vsi. Archeologický výzkum zaniklé stř̌edověké vsi na Drahanské vrchovině 1975-2005. Brno.

BELÉNYESY, M., 1957: Középkori mezőgazdaság-történetünk kutatási módszereiről, Agrártörténeti tanulmányok 1, 9-10.

BENČIČ, D., 2012: Polnohospodárske náradie v nálezovom fonde slovenských hradov. Nepublikovaná bakalárska práca, Katedra archeológie FF UKO Bratislava.

BENKOVÁ, E., 2015: Rastlinná produkcia vo včasnom stredoveku na Slovensku v písomných prameňoch. In: Interdisciplinárne o pol’nohospodárstve včasného stredoveku (Borzová, Z., ed.), 47-60. Nitra.

BEŇUŠ, R.-MASNICOVÁ, S., 2015: Možnost’ rekonštrukcie fyzickej aktivity na základe analýzy kostrových pozostatkov s prihliadnutím na pol’nohospodárstvo (na príklade dvoch devínskych populácií zo 
včasného stredoveku). In: Interdisciplinárne o pol’nohospodárstve včasného stredoveku (Borzová, Z., ed.), 61-81. Nitra.

BERANOVÁ, M., 1957: Slovanské žňové nástroje v 6.-12. století, PA XLVIII, 99-117.

- 1958: Počátek pluhu na československém území, AR X, 324-330.

- 1963: Pravěké žernovy v Československu. In: Vznik a počátky Slovanů 4, 181-219. Praha.

- 1966: The raising of domestic animals among Slavs in Early Middle Ages according to archaeological sources. In: Vznik a počátky Slovanů 6, 153-196. Praha.

- 1967: Hradištní nůžky v Československu, PA LVIII, 571-579.

- 1968: Hromadný nález orebního nářadí ze Smolnice a problematika oradla v Čechách v době hradištní, PA LIX, 519-542.

- 1969: Evropské zemědělství v archeologii. Praha.

- 1970: Nejstarší slovanské podkovy a počátek novodobého zápřahu koní, SbNM XXIV, 15-19.

- 1971: Středověká kosa z Bradla, AR XXIII, 63-68.

- 1972: Der Obst- und Weinbau bei den Slawen im frühen Mittelalter nach den archäologischen Quellen. In: Vznik a počátky Slovanů 7, 207-241. Praha.

- 1973: Nejstarší nález řezací stolice na píci v Čechách, AR XXV, 388-391.

- 1975: Zemědělská výroba v 11.-14. století na území Československa. Praha.

- 1980: Zemědělství starých Slovanů. Praha.

- 1980a: Způsob chovu dobytka u Slovanů v 6.-10. století. In: Slované 6.-10. století. Sborník referátů ze sympozia Břeclav-Pohansko 1978 (Dostál, B.-Vignatiová, J., edd.), 19-25. Brno.

- 1986: Origins of agricultural production in the light of coordinated experiments. In: Archaeology in Bohemia 1981-1985, 307-324. Prague.

- 1990: Slavic Scythes and Haymaking until the Beginning of the Fifteenth Century, Ethnologia Slavica 21, 129-166.

- 1991: Slavic Harvest and Harvesting Implements until the Beginning of the 15th Century, Ethnologia Slavica $23,7-36$.

- 1995: Die Ernte von unreifem Getreide im böhmischen Mittelalter. In: Res archeobotanicae, 17-24. Kiel.

- 2000: Formy chovu dobytka v 11.-13. století. In: Sborník Miroslavu Buchvaldkovi, 17-20. Most.

- 2005: Historie senoseče v Čechách podle archeologie, ASČ 9, 9-65.

- 2006: Způsoby obdělávání polí od pravěku do středověku, ASČ 10, 11-110.

BERANOVÁ, M.-HUML, V., 1970: Radlice z Vestce a některé problémy časně novověkého orebního nářadí v archeologických nálezech, AR XXII, 78-84.

BERANOVÁ, M.-KUBAČÁK, A., 2010: Dějiny zemědělství v Čechách a na Moravě. Praha.

BERANOVÁ, M.-LUTOVSKÝ, M., 2009: Slované v Čechách. Archeologie 6.-12. století. Praha.

BIALEKOVÁ, D., 1979: Orné a žatevné náradie zo slovanského hradiska v Pobedime, Agrikultúra 16, 5-25.

- 2001: Železný česák z Pobedima. In: Archaeologia mediaevalis Moravica et Silesiana I/2000. Konference Pohansko 1999, 143-149. Brno.

BORZOVÁ, Z., 2005: Pol'nohospodárske náradia a nástroje v období 6.-12. storočia na území dnešného Slovenska. Nepublikovaná dizertačná práca, Katedra archeológie FF UKF v Nitre.

- 2006: Z. Borzová: Kosáky v hroboch z obdobia včasného stredoveku na Slovensku, SlArch LIV, 209-237.

- 2009: Žatva obilným kosákom z obdobia včasného stredoveku, SlArch LVII, 258-300.

- 2010: Rýl' v období včasného stredoveku a jeho využitie (nielen) v pol'nohospodárstve, Studia historica Nitriensia 15, 13-31.

- 2015: K funkcii a spôsobu použitia nástrojov s tulajkou vo včasnom stredoveku (nielen) v polnohospodárstve. In: Interdisciplinárne o pol'nohospodárstve včasného stredoveku (Borzová, Z., ed.), 83-107. Nitra. - 2016: Polnohospodárske náradie včasného stredoveku na Slovensku. Nitra.

BORZOVÁ, Z. et al., 2015: Interdisciplinárne o pol’nohospodárstve včasného stredoveku. Nitra.

BORZOVÁ, Z.-PAŽINOVÁ, N., 2010: Vybrané problémy súčasného polnohospodárstva v Sedmohradsku (prípadová štúdia z obce Bezid), Ethnologia actualis Slovaca 10, 169-187.

BORZOVÁ, Z.-PIETA, K.-JAKUBČINOVÁ, M., v tlači: Bojná 3. Polnohospodárske náradie z hradiska Valy a jeho zázemia. 
ČAPLOVIČ, D.-HAJNALOVÁ, E.-HANULIAK, M.-RUTTKAY, A., 1985: Stredoveká dedina na Slovensku ako základný fenomén feudálnej ekonomiky - Das mittelalterliche Dorf der Slowakei als Grundphänomen der feudalen Ökonomik, AH 10, 11-23.

ČERVINKA, I. L., 1928: Slované na Moravě a ř́íše velkomoravská. Brno.

DEMO, M., et al., 2001: Dejiny pol'nohospodárstva na Slovensku. Nitra.

DOSTÁL, B., 1975: Břeclav-Pohansko IV. Velkomoravský velmožský dvorec. Brno.

- 1976: Zemědělská výroba na území ČSSR v 6.-10. století - Die Landwirtschaft auf dem Gebiet der heutigen ČSSR im 6.-10. Jahrhundert, AH 1, 9-26.

DRESLER, P., 2016: Břeclav-Pohansko VIII. Hospodářské zázemí centra nebo jen osady v blízkosti centra? Brno.

DRESLER, P.-BERAN, V., 2019: Zemědělské nástroje raně středověkého obyvatelstva Pohanska u Břeclavi, PA CX, 237-306.

DRESLEROVÁ, D.-VENCLOVÁ N., 2007: Železná výbava vesnické komunity (nejen) v době laténské, AVJČ 20, 347-356.

EISNER, J., 1941: Ein Hortfund der älteren Burgwallzeit aus der Slowakei, Altböhmen u. Altmähren 1, $153-171$.

- 1939/1946: Sídliště ze starší doby hradištní v slovenském Pomoraví, PA XLII, 94-105.

- 1948: Základy kovářství v době hradištní v Československu, Slavia Antiqua I, 367-396.

- 1952: Devínska Nová Ves. Slovanské pohřebiště. Bratislava.

FILIP, J., 1949: Slovanské zemědělství v Československu, Český lid 4, 194-199.

FROLEC, V., 1972: Das Rebmesser in den tschechischen Ländern. In: Vznik a počátky Slovanů 7, $243-275$. Praha.

GEISLER, M.-KOHOUTEK, J., 2014: Vysoké pole - Kláštov. Inventář hromadných nálezů železných předmětů a shrnutí terénních výzkumních sezon 2005-2007. Brno.

GOGOVÁ, S., 2011: Archeológia a múzejná prezentácia. Nitra.

HABOVŠTIAK, A., 1965: Pol’nohospodárstvo na Slovensku v 9.-11. storočí. In: O počiatkoch slovenských dejín (Ratkoš, P., ed.), 55-80. Bratislava.

- 1971: Hmotná kultúra stredovekých dedín vo svetle doterajšieho archeologického výskumu na Slovensku, Agrikultúra 10, 7-28.

- 1977: Archeológia pre poznanie pol’nohospodárstva na Slovensku v stredoveku, Vlastivedný časopis 26 , 68-78.

HAMPEL, J., 1880: A Nemzeti Múzeum régiségosztályának gyarapodása, Archaeologiai Értesítő 14, 33-38.

- 1881: A Nemzeti Múzeum régiségosztályának gyarapodása, Archaeologiai Értesítő, I. kötet, 276-285.

- 1882: A Magyar Nemzeti Múzeum érem- és régiségtár gyarapodása, Archaeologiai Értesítő 15, 60-78.

HANULIAK, M., 2004: Predmety pol'nohospodárskeho charakteru z vel'komoravských hrobov. In: Zborník na počest' Dariny Bialekovej (Fusek, G., ed.), 111-114. Nitra.

- 2004a: Vel'komoravské pohrebiská. Pochovávanie v 9.-10. storočí na území Slovenska. Nitra.

HENNING, J., 1987: Südosteuropa zwischen Antike und Mittelalter. Schriften zur Ur- und Frühgeschichte 42. Berlin.

HLAVATÁ, J., 2008: Hospodárske stratégie sídlisk v období včasného stredoveku na základe archeobotanickej analýzy a syntézy archeologických prameňov. Nepublikovaná diplomová práca, Katedra archeológie FF UKF v Nitre.

- 2015: Archeobotanické nálezy rastlín a ich vypovedacia schopnost' vo vzt’ahu k pol'nohospodárstvu včasného stredoveku. In: Interdisciplinárne o pol’nohospodárstve včasného stredoveku (Borzová, Z., ed.), 9-44. Nitra.

HLUBEK, F., 1846: Die Landwirtschaftslehre. Wien.

HRAŠE, K. J., 1892: Nálezy ve tvrzce Batňovické u Úpice, PA XV, 287-292.

HRDLIČKA, L., 1972: Předběžné výsledky výzkumu v Praze 1 na Klárově, AR XXIV, 644-663.

HYLMANOVÁ, L., 2012: Hmotná kultura středověké usedlosti. Zaniklý Spindelbach v Krušných horách. Nepublikovaná bakalárska práca, Ústav pro pravěk a ranou dobu dějinnou FF UK.

- 2016: Každodennost středověké venkovské usedlosti. Výpověd' drobné hmotné kultury, Ústav pro pravěk a ranou dobu dějinnou FF UK. 
JIRÁSEK, J., 1968: Zemědělské nářadí poddanské usedlosti v našich zemích v době „zemědělské revoluce“, VVM 20, 208-227.

KALIČIAKOVÁ, Z., 2013: Hospodárske objekty ako doklad rastlinnej a živočíšnej produkcie v stredoveku na území Slovenska. Nepublikovaná diplomová práca, Katedra archeológie FF UKF v Nitre.

KALOUSEK, F.-DOSTÁL, B.-VIGNATIOVÁ, J.-ŠIK, A., 1977-1978: Třetí pětiletí archeologického výzkumu Břeclavi-Pohanska (1969-1973), SPFFBU E 22-23, 155-175.

KAVÁN, J., 1970: Hřeblovité nástroje a jejich problematika, Sborník ČSSA, 123-131.

KLÁPŠTĚ, J.-SMETÁNKA, Z., 1982: Archeologický výzkum české stř̌edověké vesnice v letech 1971-1981 Archäologische Untersuchungen mittelalterlicher Dörfer Böhmens in den Jahren 1971—1981, AH 7, 11-31.

KLÍMA, B.-PTÁČEK, L., 2006: K problematice raně středověkých srpů a opravám jejich čepelí. In: Ve službách archeologie VII (Hašek, V.-Nekuda, R.-Ruttkay, M., edd.), 403-413. Brno.

KLÍMA, B.-PTÁČEK, L.-STRÁNSKÝ, K., 2008: Srpy velkomoravského hradiště v Mikulčicích a jejich kovářské zpracování. In: Ve službách archeologie 1/08 (Hašek, V.-Nekuda, R.-Ruttkay, M., edd.), 256-270. Brno.

KLÍR, T., 2008: Osídlení zemědělsky marginálních půd v mladším stř̌edověku a raném novověku. Praha.

KOVÁČ, J., 2013: Hromadný nález železných predmetov z Bratislavského hradného vrchu, ZbSNM - Archeológia 23, 97-104.

KOŘAN, J., 1946: Staré české železářství. Praha.

KRAJÍC, R., 1984: Současný stav poznání hmotné kultury stredověké vesnice na Táborsku, Husitský Tábor 6-7, 47-82.

-2003: Sezimovo Ústí. Archeologie středověkého poddanského města 3. Kovárna v Sezimově Ústí a analýza výrobků ze železa. Díl I, II. Praha.

KRAMAŘíK, J., 1959: Dřevěné rýče se železným okutím v českých zemích, Československá etnografie 7, 244-261.

- 1960: Odpověd’ Leopoldu Schmidtovi, Československá etnografie 8, 208-209.

KRASKOVSKÁ, L., 1970: Železné nástroje v slovansko-avarských hroboch, SbNM A XXIV, 99-104.

KUDLÁČEK, J., 1965: O vzniku staroslovanského pluhu, ŠZ AÚ SAV 15, 107-166.

KUDRNÁČ, J., 1960: Zemědělství starých Slovanů, Dějiny a současnost 2, 1-3.

LONGAUEROVÁ, M.-KOCICH, J., 1993: Structure of the early-medieval steel sickles from Pobedim and Šebastovce. In: Actes du XIIe Congrès international des sciences préhistoriques et protohistoriques. Bratislava, 1-7 Septembre 1991, 254-259. Bratislava.

LONGAUEROVÁ, M.-KOCICH, J.-LONGAUER, S., 1995: Porovnanie štruktúry kosákov z rôznych historických období, ŠZ AÚ SAV 31, 217-230.

MĚCHUROVÁ, Z., 1997: Konůvky - zaniklá stř̌edověká ves ve Ždánickém lese. Studie Archeologického ústavu Akademie věd ČR v Brně XVII/1. Brno.

- 2008: Jak se pracovalo na poli. Srovnání zemědělského nářadí ze zaniklých středověkých vsí s etnografickými sbírkami - Wie auf dem Feld gearbeitet wurde: Ein Vergleich zwischen den Ackerbaugeräten aus mittelalterlichen Ortswüstungen und ethnographischen Sammlungen, AH 33, 129-143.

- 2016: Chvála středověké každodennosti. Pohled do archeologických sbírek objektivem Silvie Doleželové. Brno.

MICHÁLEK, J.-LUTOVSKÝ, M., 2000: Hradec u Němětic. Sídlo halštatské a raně středověké nobility v česko-bavorském kontaktním prostoru. Strakonice - Praha.

MUSIL, J., 2004: Experiment s replikami středověkého okovaného rýče, Rekonstrukce a experiment v archeologii 5, 223-232.

- 2004a: Nálezy kování dřevěných rýčů ve východních Čechách se zvláštním zřetelem ke Chrudimsku, Chrudimský vlastivědný sborník 8, 43-54.

- 2008: Nové nálezy kování dřevěných rýčů a lopat z východních Čech, ČSPS 116, 240-246.

MÜLLER, R., 1982: A mezőgazdasági vaseszközök fejlődése Magyarországon a késővaskortól a törökkor végéig. Zalai gyüjtemény 19 . Zalaegerszeg.

NEKUDA, V., 1975: Pfaffenschlag: zaniklá středověká ves u Slavonic. Brno.

- 2002: Zemědělská usedlost ve středověké vesnici na Moravě. Brno. 
NIEDERLE, L., 1916: Nejstarší české pluhy, Národopisný věstník českoslovanský 11, 1-3.

- 1917: Příspěvek k poznání starého slovanského zemědělství, Národopisný věstník českoslovanský 12, 1-19.

- 1921: Slovanské starožitnosti. Život starých Slovanů. III/1. Praha.

- 1934: Slovanské starožitnosti. Praha.

PETRÍK, J.-MIHOK, L., 2004: Archeometalurgická analýza kosákov, Archaeologia technica 15, 28 -31.

PLEINER, R., 1959: Metallographische Untersuchungen von vor- und frühgeschichtlichen eisernen Gegenständen aus der Tschechoslowakei, Stahl und Eisen 79, 284-298.

- 1962: Staré evropské kovářství. Praha.

- 1965: Výroba zemědělských nástrojů na Velké Moravě. In: Velká Morava. Almanach, 130-133. Brno.

- 1967: Die Technologie des Schmiedes in der grossmährischen Kultur, SlArch XV, 77-135.

PLEINER, R.-PLZÁK, F.-QUADRAT, O., 1956: Poznámky k výrobní technice staroslovanských čepelí, PA XLVII, 314-334.

POLÁČEK, L., 2003: Landwirtschaftliche Geräte aus Mikulčice. In: Studien zum Burgwall von Mikulčice V (Poláček, L., ed.), 591-707. Brno.

POLLA, B., 1996: Archeológia na Slovensku v minulosti. Martin.

REICHENBACH, K., 2004: Sicheln in mittelalterlichen Gräbern in der Slowakei, AH 29, 549-560.

ŘÍHOVÁ, D., 1962: K počiatkom slovanských žatevných nástrojov na Slovensku, Agrikultúra 1, 6-14.

SEDLÁČKOVÁ, H., 1977: Výzkum zaniklé středověké vesnice u Střihova, okr. Nymburk. In: Středověká archeologie a studium počátků měst, 274-276. Praha.

SCHMIDT, L., 1957: Der randbeschlagene Holzspaten in Ostmitteleuropa, Deutsches Jahrbuch für Volkskunde 3, 388-406.

SLANÁ, A., 2017: Stredoveké žacie a zberové náradie v zbierkach Považského múzea v Žiline, Vlastivedný zborník Považia 28, 39-69.

SLIVKA, M., 1981: Stredoveké hutníctvo a kováčstvo na východnom Slovensku. 3. čast', Historica Carpatica 12, 211-275.

SMETÁNKA, Z., 1956: Hrábě se železnými hřeby, Český lid 43, 268-270.

- 1965. Současný stav archeologického výzkumu hmotné kultury zemědělských osad X.-XV. století v Čechách, Čs ̌̌H 13, 239-268.

- 1992: Legenda o Ostojovi. Archeologie obyčejného života v raně středověkých Čechách. Praha.

STARÁ, M., 1956: K otázce vzniku orebního nářadí „sochy“, Národopisný věstník českoslovanský XXXIII, 278-299.

- 1958: Nové př́íspěvky k otázkám staroslovanských oradel z hlediska Niederlových „Slovanských starožitností“. In: Vznik a počátky Slovanů 2, 317-369. Praha.

- 1959: Soudobé způsoby studia slovanských oradel, Československá etnografie 7, 206-215.

STEENSBERG, A., 1943: Ancient harvesting implements. København.

ŠACH, F., 1961: Rádlo a pluh na území Československa 1. Nejstarší orební nářadí, Vědecké práce Zemědělského muzea 2, 23-155.

- 1962: K vývoji slovenského orebného nářadí na základě muzejních sbírek, Československá etnografie 10 , 217-239.

- 1963: Soustava oradel Starého světa a zařazení nářadí z území Československa, Vědecké práce Zemědělského muzea 1963, 173-231.

- 1968: Počátky orebného nářadí v českých zemích (od pravěku do 15. století), Etnografický atlas 1, 141-144.

- 1977: Potažní zvířata v českých zemích v průběhu šesti století, Vědecké práce Zemědělského muzea 16, 91-120.

- 1977a: Rádlo a pluh na území Československa II. Nejstarší písemné a ikonografické doklady, Vědecké práce Zemědělského muzea 16, 91-120.

ŠAUROVÁ, D., 1973: Zemědělské nástroje z Konůvek na Slavkovsku, AR XXV, 336-339.

TOČÍK, A., 1983: Vel'komoravský železný depot z Čeboviec, ŠZ AÚ SAV 20, 207-230.

TURČAN, V., 2006: Depoty z Bojnej v zbierkach Archeologického múzea SNM. In: Bojná. Hospodárske a politické centrum Nitrianskeho kniežatstva (Pieta, K.-Ruttkay, A.-Ruttkay, M., edd.), 159-166. Nitra.

- 2012: Depoty z Bojnej a včasnostredoveké hromadné nálezy železných predmetov uložené v zbierkach SNM - Archeologického múzea. ZbSNM - Archeológia - Supplementum 6. Bratislava. 
VALAŠEKOVÁ, E., 2014: Nástroje k spracovaniu obilia v stredoveku na Slovensku. Nepublikovaná diplomová práca, Katedra archeológie FF UKF v Nitre.

- 2015: Rotačné mlynčeky a ich úloha v pol’nohospodárstve včasného stredoveku. In: Interdisciplinárne o pol’nohospodárstve včasného stredoveku (Borzová, Z., ed.), 109-157. Nitra.

VÁLKA, M., 2014: Homo faber. Tradiční zemědělství a lidová výroba. Brno.

VEDRALOVÁ, L., 2009: Zemědělský rok ve středověké vesnici, nástroj v archeologických dokladech. Nepublikovaná diplomová práca, Ústav pro pravěk a ranou dobu dějinnou FF UK.

VENDTOVÁ, V., 1964: Prehl'ad slovanských lokalít v Pobedime a okolí, ŠZ AÚ SAV 14, 161-173.

- 1969: Slovanské osídlenie Pobedima a okolia, SlArch XVII, 119-233.

VIGNATIOVÁ, J., 1973: Počátky pěstování révy vinné ve světle archeologických nálezů. In: Vinohradnictví (Zemek, M. a kol.), 14-22. Brno.

VÍCH, D., 2010: Neznámá vrcholně středověká fortifikace na k. ú. Lanšperk, CB 12, 319-343.

VYSLOUŽIL, P., 2010: Význam orby v archeologii. Nepublikovaná diplomová práca, Ústav archeologie a muzeologie FF MU, Brno.

\section{Zusammenfassung}

Landwirtschaftliche Geräte im Mittelalter aus Sicht der tschechischen und slowakischen Archäologie - Entwicklungstendenzen und Perspektiven der weiteren Forschung

Der vorliegende Beitrag soll einen Forschungsquerschnitt des gegebenen Themas ab den Anfängen des Interesses an mittelalterlichen landwirtschaftlichen Geräten bis zu den heutigen Ansätzen zur betreffenden Problematik geben. Eine weitere Absicht des Beitrags ist es, auf das lebenslange Interesse und auf die bislang unübertroffene Arbeit von Magdalena Beranová auf dem Gebiet der mittelalterlichen Landwirtschaft aufmerksam zu machen.

Das Interesse der Archäologen an der Landwirtschaftsproblematik, bzw. an landwirtschaftlichen Geräten, könnte man in drei Perioden untergliedern.

Die Anfänge des Interesses an landwirtschaftlichen Geräten reichen bis in die Zeit des 18.-19. Jahrhundert zurück. In dieser sog. Sammelperiode haben verschiedene regionale historische und archäologische Vereine und Gesellschaften sowie andere gelehrte Gesellschaften eine wichtige Rolle gespielt, die unter anderem mit ihren Aktivitäten zum Ziel hatten, „Antiquitäten“, also auch landwirtschaftliche Geräte zu sammeln und zu retten. In der ersten Hälfte des 19. Jahrhunderts entstehen an Mittelschulen sog. Kabinette, die auch archäologische Funde gesammelt und zusammengetragen haben. Man begann damit, die ersten archäologischen Grabungen und Untersuchungen durchzuführen, dank denen auch Gegenstände entdeckt wurden, die zu verschiedenen landwirtschaftlichen Tätigkeiten gedient hatten. Dank den oben erwähnten Aktivitäten gelangten landwirtschaftliche Geräte auch in die (nicht nur archäologogische) Fachliteratur.

Ein weiterer Einschnitt in der Forschung zur gegebenen Problematik ist die Zeit der fünfziger bis sechziger Jahre des 20. Jahrhunderts. In jener Zeit entstanden, auch dank einer größeren Fülle an entdeckten und publizierten landwirtschaftlichen Geräten, mehrere bedeutende Arbeiten, welche die ersten Bearbeitungen des betreffenden Themas enthielten. Bei ihnen handelt es sich vornehmlich um die Beschreibung, Klassifizierung und um eine typologisch-chronologische Analyse von mehreren Arten der betreffenden Artefakte und um die Rekonstruktion der mit landwirtschaftlichen Geräten verrichteten Tätigkeiten. In diesen Arbeiten tauchen erstmals eine genauere Definition der einzelnen Arten an landwirtschaftlichen Geräten wie auch mehrere Termini auf, die mit der betreffenden Problematik zusammenhängen und zumeist der ethnologischen Terminologie entlehnt wurden. Auf dieser Grundlage entstand eine Typologie mehrerer Arten von Geräten, die zumeist auf einer Formendifferenzierung der jeweiligen Funktion der einzelnen Geräte basiert. In den darauffolgenden Jahrzehnten war es vor allem Magdalena Beranová, die sich der Erforschung mittelalterlicher Feldgeräte gewidmet hat. 
Eine Zunahme des Interesses an der Thematik der Landwirtschaft, der landwirtschaftlichen Geräte, der Verarbeitung und Weiterbearbeitung von landwirtschaftlichen Erzeugnissen kann in der tschechischen und slowakischen archäologischen Fachliteratur im ersten Jahrzehnt des 21. Jahrhunderts beobachtet werden. In diesem Zeitraum entstehen mehrere zusammenfassende Arbeiten zu diesem Thema (z.B. Beranová-Kubačák 2010; Borzová 2015; 2016). Im Unterschied zu den vorhergehenden Jahrzehnten konzentrieren sich die Arbeiten auch auf die Analyse und komplexe Auswertung von landwirtschaftlichen Geräten von konkreten Fundstellen (z.B. Dresler-Beran 2019; Geisler-Kohoutek 2014; Kováč 2013; Krajíc 2003; Poláček 2003; Turčan 2012). Das Thema ist auch im Rahmen von Bachelor-, Diplomarbeiten und Dissertationen sehr beliebt.

Obwohl die Fachliteratur zu diesem Thema zahlenmäßig insgesamt sehr umfangreich ist, weist die Problematik und Erforschung von landwirtschaftlichen Geräten bislang Lücken auf, die dank einer weiteren Erforschung des Themas geschlossen werden könnten.

In erster Linie geht es um die uneinheitliche Terminologie bei der Definition von landwirtschaftlichen Geräten, ihrer Gattungsskala, der einzelnen Typen und Teile.

Als Mangel in Fragen der Erforschung von landwirtschaftlichen Geräten kann man das sehr häufige Fehlen einer detaillierten Beschreibung der Geräte, einer schematischen Darstellung der einzelnen Teile sowie metrischer Angaben ansehen.

Ein weiteres, bisher ungeklärtes Schlüsselthema ist die Typologie landwirtschaftlicher Geräte. Die bisherigen Typologien basieren auf den unterschiedlichen Formen, was oftmals das einzige Kriterium der typologischen Klassifizierung ist.

Die Rekonstruktion des Gesamtaussehens eines landwirtschaftlichen Gerätes ist ein weiteres Thema, dass größere Aufmerksamkeit verdient.

Als weiteres Ziel der Erforschung des betreffenden Themas könnte man eine bislang fehlende komplexe Bearbeitung landwirtschaftlicher Geräte aus dem jeweils untersuchten Gebiet abstecken. In diesem Zusammenhang wäre es interessant (und wünschenswert), das archäologische Material aus dem gesamten Mittelalter zu bearbeiteten. Eine Analyse und ein Vergleich der Forschungsergebnisse bzgl. der landwirtschaftlichen Geräte des frühen Mittelalters einerseits und des hohen und späten Mittelalters, ggf. der frühen Neuzeit andererseits könnten interessante Ergebnisse zu den Fragen der landwirtschaftlichen Produktion und Veränderungen in der Landwirtschaft sowie neue Erkenntnisse auf dem Gebiet der Methoden zur Erforschung landwirtschaftlicher Geräte liefern.

Dem oben festgelegten Ziel ging die Bearbeitung und Veröffentlichung des Fundbestandes landwirtschaftlicher Geräte von Schlüsselfundstellen aus frühneuzeitlichen Siedlungsagglomerationen, mittelalterlichen Dörfern, Adelssitzen - bzw. Burgen voraus. Wie aus den mehreren, oben erwähnen Thesen hervorgeht, ist bei der Erforschung von landwirtschaftlichen Geräten eine interdisziplinäre Zusammenarbeit, bzw. die Heranziehung verschiedener nicht archäologischer Analysen unabdingbar. In dieser Richtung weist die Erforschung von landwirtschaftlichen Geräten, wie auch der gesamten Landwirtschaft, beträchtliche Lücken auf.

Nicht zuletzt möchten wir noch auf ein vergessenes, die besagte Problematik betreffendes Thema aufmerksam machen. Dabei geht es um eine Thematik, die mit einer anderen Betrachtungsweise von Gegenständen zusammenhängt, die in gewisser Weise nicht nur auf die Arbeit selbst abzielt, sondern auch auf andere Lebensbereiche, auf das Denken, die Bräuche und die Geisteswelt des mittelalterlichen Bauers. Antworten sollten wir in Thesen suchen, welche die Pflege von landwirtschaftlichen Geräten, die ästhetische Seite, die realen Werte dieser Gegenstände und die geistige Bedeutung betreffen.

Die vorliegende Arbeit entstand im Rahmen des Förderprojektes 2/0037/17 der Agentur VEGA „Die Rolle der Sachkultur bei der Ausformung ökonomischer, sozialer und interethnischer Beziehungen in mittelalterlichen Kommunitäten“. 
doc. Mgr. Zuzana Borzová, PhD., Katedra archeológie Filozofickej fakulty Univerzity Konštantína Filozofa v Nitre, Hodžova 1, 94974 Nitra, Slovenská republika, zborzova@ukf.sk 
